\title{
Snow-atmosphere coupling and its impact on temperature variability and extremes over North America
}

\author{
G. T. Diro ${ }^{1} \cdot$ L. Sushama $^{1} \cdot$ O. Huziy ${ }^{1}$
}

Received: 20 December 2016 / Accepted: 4 July 2017 / Published online: 11 July 2017

(C) The Author(s) 2017. This article is an open access publication

\begin{abstract}
The impact of snow-atmosphere coupling on climate variability and extremes over North America is investigated using modeling experiments with the fifth generation Canadian Regional Climate Model (CRCM5). To this end, two CRCM5 simulations driven by ERA-Interim reanalysis for the 1981-2010 period are performed, where snow cover and depth are prescribed (uncoupled) in one simulation while they evolve interactively (coupled) during model integration in the second one. Results indicate systematic influence of snow cover and snow depth variability on the inter-annual variability of soil and air temperatures during winter and spring seasons. Inter-annual variability of air temperature is larger in the coupled simulation, with snow cover and depth variability accounting for $40-60 \%$ of winter temperature variability over the Mid-west, Northern Great Plains and over the Canadian Prairies. The contribution of snow variability reaches even more than $70 \%$ during spring and the regions of high snow-temperature coupling extend north of the boreal forests. The dominant process contributing to the snow-atmosphere coupling is the albedo effect in winter, while the hydrological effect controls the coupling in spring. Snow cover/depth variability at different locations is also found to affect extremes. For instance, variability of cold-spell characteristics is sensitive to snow cover/depth variation over the Mid-west and Northern Great Plains, whereas, warm-spell variability is sensitive to snow variation primarily in regions with climatologically extensive snow cover such as northeast Canada and
\end{abstract}

G. T. Diro

diro@sca.uqam.ca

1 Centre ESCER, Université du Québec à Montréal (UQAM), 201 Ave. President-Kennedy, Montreal, QC H2X 3Y7, Canada the Rockies. Furthermore, snow-atmosphere interactions appear to have contributed to enhancing the number of cold spell days during the 2002 spring, which is the coldest recorded during the study period, by over $50 \%$, over western North America. Additional results also provide useful information on the importance of the interactions of snow with large-scale mode of variability in modulating temperature extreme characteristics.

Keywords Snow-atmosphere $\cdot$ Snow depth $\cdot$ Snow cover $\cdot$ Extremes $\cdot$ North America $\cdot$ Regional climate model

\section{Introduction}

Several studies, including the Global Land Atmosphere Coupling Experiment (GLACE, Guo et al. 2006; Koster et al. 2006), have illustrated that land, in particular soil moisture, plays an important role in modulating the climate of selected regions such as the Great Plains during summer. In cold seasons, the most likely interactions between land and atmosphere could be manifested via snow-atmosphere coupling. Previous studies, that examined the role of snow on climate, using either observational analysis (Walsh et al. 1982, 1985; Karl et al. 1993; Groisman et al. 1994; Betts et al. 2014) or climate models (Cohen and Rind 1991; Cohen and Entekhabi 2001; Yang et al. 2001; Gong et al. 2004; Dutra et al. 2011; Xu and Dirmeyer 2011), found strong links between snow cover extent and temperature anomalies.

The challenge with observational studies is that it is usually difficult to disentangle the atmospheric response to snow anomalies (or variability) from other large-scale forcings. In this context, carefully designed global and/ or regional climate model experiments can be used to 
isolate the effect of snow on atmosphere from all other potential factors. Such previous modeling studies have followed different approaches. For instance, some studies have investigated the influence of snow on mean atmospheric circulation by prescribing idealized or realistic snow cover/depth anomalies (e.g., Cohen and Entekhabi 2001; Gong et al. 2004; Sobolowski et al. 2010), while other studies focused on understanding the role of snow variation in modulating intra-seasonal (Xu and Dirmeyer 2011, 2013) or inter-annual atmospheric variability (e.g., Yang et al. 2001; Kumar and Yang 2003; Dutra et al. 2011).

These modeling studies, however, disagree on the spatial extent of the snow-atmosphere coupling maxima. Xu and Dirmeyer (2011), for example, through GLACE type experiments, investigated the impact of snow variability on intra-seasonal climate variability and found strong snow-atmosphere coupling over high-latitude regions of eastern North America during late spring period. Dutra et al. (2011), on the other hand, focused on the impact of inter-annual snow variability on temperature and found strong snow-temperature coupling for the spring season over northwestern U.S. and southern Canada. However, the coupling strength for northern Canada is rather weak compared to the result of Xu and Dirmeyer (2011). Although the two studies differ in their experimental design and in the coupling metrics used to evaluate the coupling strength, the difference in the spatial distribution of the coupling maxima could partly be due to the differences in the snow parameterizations. Furthermore, Pedersen and Winther (2005) and Pirazzini (2009) highlighted substantial differences in the snow parameterization schemes among climate models. In particular, Snow albedo parameterization schemes in land surface models generally vary from a simple diagnostic approach that depends only on surface temperature (e.g., Xue et al. 1991; Cox et al. 1999; Roeckner et al. 2003) to a more complex and prognostic one that accounts for snow aging (Verseghy 1991; Dutra et al. 2010) and snow type (Brun et al. 1992). Similarly, the snow cover fraction within a grid cell is parameterized with various degrees of complexity. The simplest parameterization scheme considers snow cover as a function of snow depth or snow mass (e.g., Verseghy 1991; Douville et al. 1995; Dutra et al. 2010). Other schemes add a dependency of seasonality to the relationship between snow cover and snow depth/ snow mass by considering the ratio of the density of the instantaneous snow to that of a fresh snow (e.g., Niu and Yang 2007). Snow density is also modeled differently amongst climate models ranging from a simple exponential increase of density with time (Verseghy 1991; Douville et al. 1995), to a more complex parameterization that takes into account processes such as the overburden of snow, thermal metamorphism, compaction related to liquid water in snow (Dutra et al. 2010). A recent study comparing snow model parameterizations for alpine region by Essery et al. (2013) concluded that there is no clear association between model complexity and performance. However, they emphasized that having a prognostic representation of snow albedo and snow density will yield consistent results. The snow parameterization differences among models discussed above, highlight the need for more modeling studies to further enhance our understanding of snow-atmosphere interactions. One of the goals of this study is therefore to quantify snowatmosphere coupling strength in the fifth generation Canadian Regional Climate Model (CRCM5).

The less explored aspect of snow-atmosphere coupling is the role of snow in modulating characteristics of extreme events such as cold spells also known as cold air outbreaks (CAO) and extreme warm spells during cold seasons. Therefore, this study also focuses on the impact of snow variability on temperature extremes, particularly the frequencies, during cold seasons using carefully designed experiments with CRCM5.

The rest of the article is structured as follows: description of the model, data and methods are given in Sect. 2. Snow-temperature coupling and related processes are analyzed in Sect. 3. Section 4 presents relation between snow cover/depth and temperature extremes, followed by summary and main conclusions in Sect. 5 .

\section{Model, data and methodology}

\subsection{Model and experimental design}

The model used in this study is CRCM5 (Zadra et al. 2008; Martynov et al. 2013), which is based on the Global Environmental Multi-scale (GEM) Model (Côté et al. 1998). The model uses a non-hydrostatic dynamical core with a hybrid vertical coordinate. The numerical scheme is composed of a two-time level, semi-Lagrangian, implicit scheme. Detailed description of the model can be found in Martynov et al. (2013) but a brief summary of the physics parameterization is presented here. Deep convection in the model follows Kain and Fritsch (1992), while shallow convection is based on Bélair et al. (2005). The resolvable large-scale precipitation is computed following Sundqvist et al. (1989). Radiation is parameterized by Correlated $\mathrm{K}$ solar and terrestrial radiation of $\mathrm{Li}$ and Barker (2005). The planetary boundary layer scheme follows Benoit et al. (1989) and Delage (1997), with some modifications as described in Zadra et al. (2012). Both resolved and subgrid lakes are represented by the FLake model (Martynov et al. 2012). 
For representing land surface processes, CRCM5 makes use of the Canadian Land Surface Scheme (CLASS, Verseghy 1991, 2009; Verseghy et al. 1993), which allows flexible soil layer configuration; in this study 26 soil layers that extent till $60 \mathrm{~m}$ are considered. CLASS adopts a pseudo-mosaic approach and divides the land fraction of each grid cell into a maximum of four subareas: bare soil, vegetation, snow over bare soil, and snow with vegetation. The energy and water budget equations are first solved for each subarea separately and then averaged over the grid cell. In CLASS, a single variable depth layer is used to represent snow and snow depth determines the snow cover. Snow cover is considered 100 percent for snow depths greater than $0.10 \mathrm{~m}$. Otherwise snow cover is computed as snow depth divided by the threshold value of $0.10 \mathrm{~m}$. Although this formulation of snow cover is simple, recent evaluation of CLASS for eastern Canada by Verseghy et al. (2017) found that the simulated snow cover agrees well with satellite derived observations. The grid-averages snow depth in CLASS is computed from the grid-average snow mass and snow density. The evolution of snowpack is modelled in CLASS by taking into account the addition of new snowfall, modifications due to phase changes, aging, etc. The aging process of the snowpack is considered through the prognostic equations of snow density and snow albedo.

To investigate the role of snow (both depth and cover) in modulating the climate of North America, a suite of CRCM5 experiments are carried out. The experiments consist of two (coupled and uncoupled) CRCM5 simulations. The coupled simulation covers the 1981-2010 period driven by the European Centre for Medium-Range Weather Forecasts (ECMWF) ERA-Interim reanalysis (Dee et al. 2011) at the lateral boundaries. It has to be noted that the initial land surface conditions for both coupled and uncoupled simulations are taken from a separate reanalysis driven CRCM5 simulation initialized on September 1, 1957. The uncoupled simulation is similar to the coupled simulation, except for the evolution of snow depth. In the uncoupled simulation, at the beginning of each time step, the model derived snow depth is replaced with 3-hourly climatological values computed from the coupled simulation for the 1981-2010 period. Therefore, in the uncoupled simulation the annual cycle of snow depth as well as its spatial extent exhibits no inter-annual variation. Other snow variables such as snow temperature, snow density are allowed to evolve freely. Given that the initial conditions for the uncoupled and coupled simulations for the 1981 January 1st are the same, any difference between the coupled and uncoupled simulations is due to the inter-annual variability of the snow depth and cover.
For both simulations, the model is configured at $0.44^{\circ}$ horizontal resolution and with 56 vertical layers extending from the surface to $10 \mathrm{hPa}$. Both coupled and uncoupled simulations also share the same boundary conditions (i.e. sea surface temperature, sea ice cover and lateral atmospheric boundary conditions, all taken from ERA-interim reanalysis). The model time step for this simulation is set to $20 \mathrm{~min}$. The domain consists of $212 \times 200$ grid points and covers whole of North America and the surrounding oceans.

\subsection{Data}

The gridded daily observed maximum temperature data used for validation in this study were obtained from Maurer et al. (2002) for the U.S. and Hutchinson et al. (2009) and Hopkinson et al. (2011) for Canada. The U.S. dataset has a spatial resolution of $0.125^{\circ}$ and covers the contiguous United States. The Canadian dataset covers the Canadian land-mass south of $60^{\circ} \mathrm{N}$ and is available at $0.1^{\circ}$ resolution. This gridded dataset was developed from daily observations at Environment Canada climate stations, using a thin plate smoothing spline surface fitting method (Hutchinson et al. 2009). Surface temperature data from ERA-Interim (Dee et al. 2011) and snow depth data from NASA's Modern-Era Retrospective analysis for Research and Application (MERRA) (Rienecker et al. 2011) are also used for validation purposes.

\subsection{Methods}

The snow-atmosphere coupling strength is evaluated using the variance method similar to Diro et al. (2014). In the variance method, the contribution of interactive snow to the inter-annual variability of the climate variable of interest is computed as:

$\Delta \sigma^{2}=\frac{\sigma_{\text {coup }}^{2}-\sigma_{\text {uncoup }}^{2}}{\sigma_{\text {coup }}^{2}} \times 100 \%$

where $\sigma_{\text {coup }}$ and $\sigma_{\text {uncoup }}$ are the inter-annual standard deviations of the variable in question for the coupled and uncoupled simulations, respectively. Higher values of $\Delta \sigma^{2}$ imply strong contribution of snow on the inter-annual variability of the climate variable considered.

For analysis of temperature extreme characteristics, cold/warm-spell indices are used. A cold (warm)-spell event is defined as a period of three or more consecutive cold (warm) days, with a cold (warm) day defined as a day with daily temperature less (greater) than a pre-defined threshold. The threshold used is the 10th (90th) percentile of daily temperature for cold (warm) day, for the coupled 
simulation, following Diro et al. (2014) and Jeong et al. (2016). This threshold varies with the calendar day and grid point. The maximum duration of cold-spell/warmspell event is also computed for each grid point. As it will be shown later snow-atmosphere coupling is stronger during spring season, and therefore all the analysis related to temperature extremes are restricted to the March to May (MAM) months. The above indices are then assessed for observations and the two CRCM5 simulations, for exceptionally cold years as well as during strong ENSO years to understand the role of snow-atmosphere coupling in modulating temperature extreme characteristics through interactions with large-scale modes of variability.

\section{Basic validation and snow-atmosphere coupling strength}

\subsection{Basic validation of CRCM5}

Martynov et al. (2013) extensively assessed the performance of CRCM5 simulation over North America when driven by reanalysis and they demonstrated that the model captures many aspects including the seasonal mean climatology of precipitation and temperature over the study area. Therefore, we only provide validation of CRCM5 simulated snow climatology and inter-annual variability here. The snow depth climatology for winter and spring seasons for the 1981-2010 period from the coupled simulation and MERRA are compared in Fig. 1. The simulated snow depth in CRCM5 is overestimated over the Arctic region

\section{DJF}
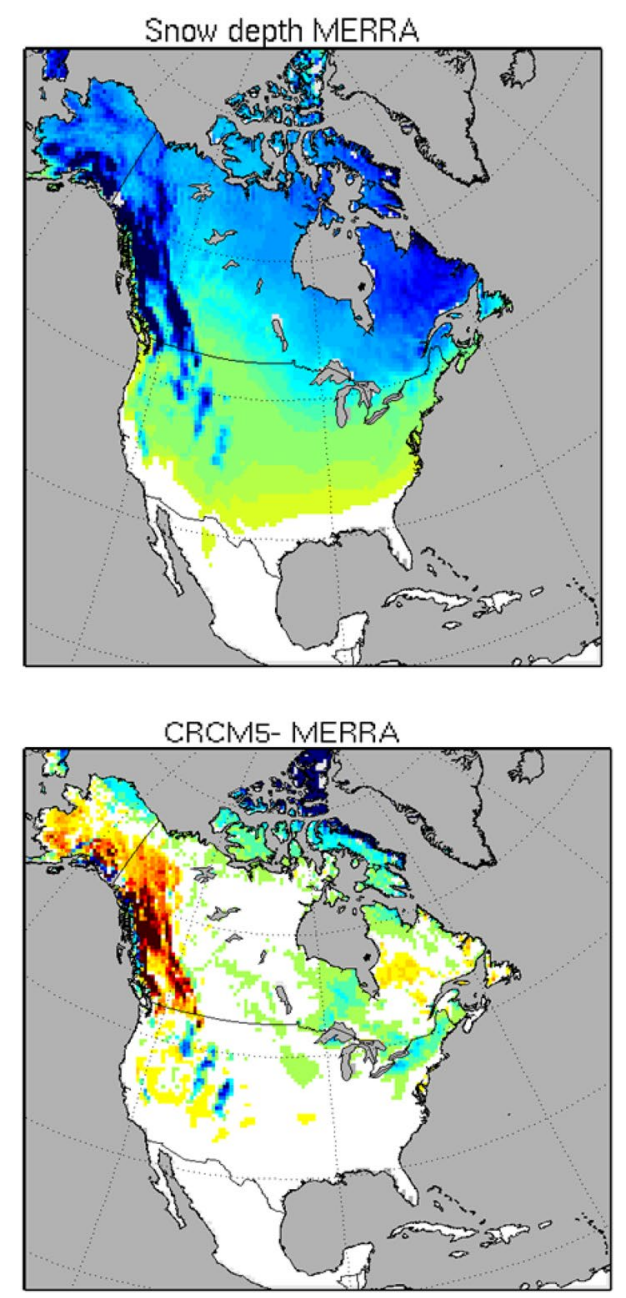

MAM

Snow depth MERRA
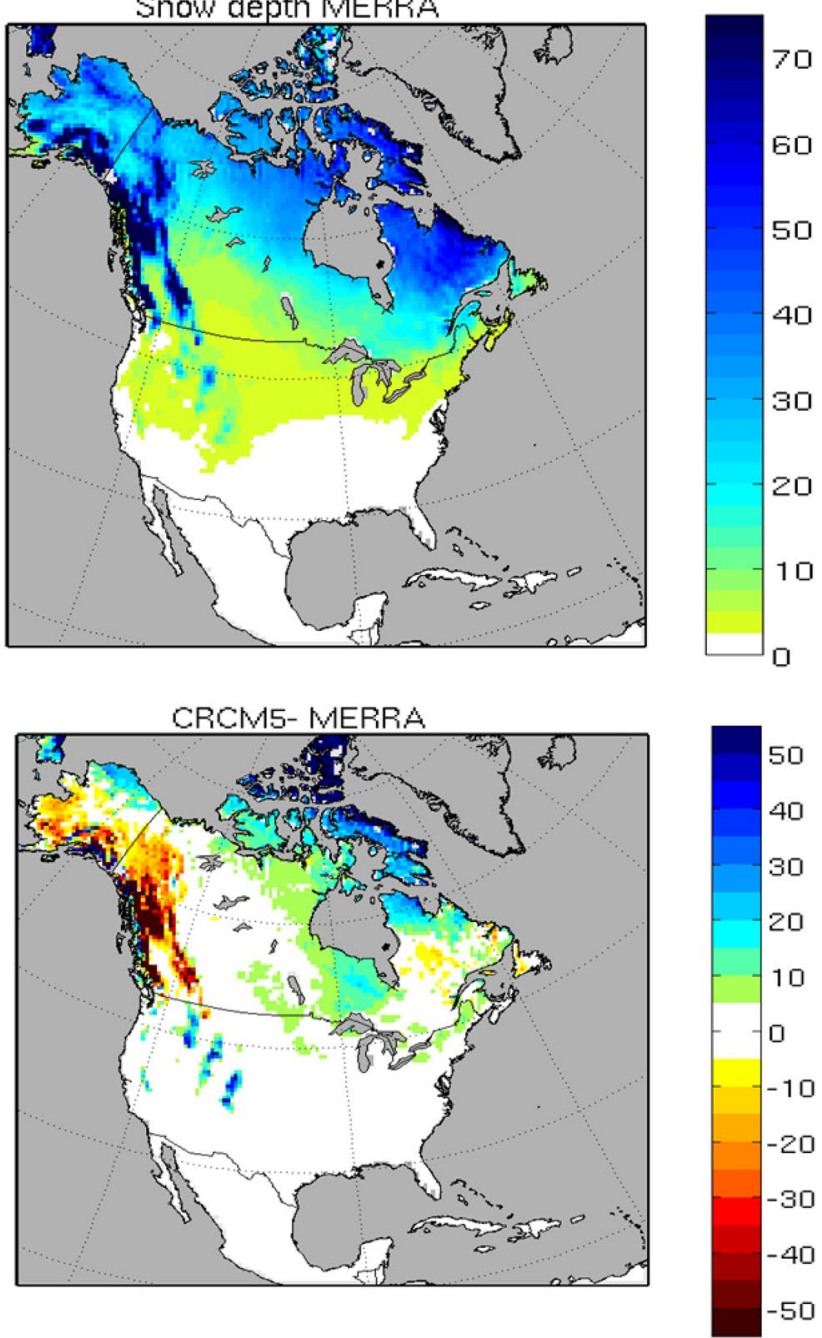

Fig. 1 Snow depth climatology [cm] for winter (top left) and spring (top right) from MERRA. Bottom row shows CRCM5 biases with respect to MERRA (i.e. CRCM5-MERRA) for winter (left) and spring (right) 
and over the southern limit of the snow cover region, but underestimated over western Canada. In general, CRCM5 simulated the spatial pattern of the snow depth reasonably well, including the high values over the mountainous areas and over the high latitude regions and low values over the northern Great Plains and lower latitudes. It has to be noted that MERRA is a reanalysis product and has its own limitations. For instance, a recent validation of reanalysis and observation based gridded products by Snauffer et al. (2016) illustrated that MERRA underestimates snow water equivalent over western Canada when compared against insitu measurements.

In addition to the mean values, it is also important for CRCM5 to have an overall acceptable performance in reproducing the inter-annual variability. This is compared in Fig. 2. MERRA shows higher values of inter-annual variability over eastern Canada, Alaska and over the Rocky mountains in both seasons, although the variability is generally stronger in winter than in spring. CRCM5 generally captured the spatial pattern of the variability such as the high values over northeast Canada, Alaska and over the Rocky Mountains. However, the variability is overestimated over northern U.S. in winter and almost everywhere, except over western Canada, during spring in CRCM5. Both MERRA and CRCM5 agree that the variability is higher over regions with high values of snow depth (Fig. 1). Correlation analysis (not shown) also indicates that CRCM5 reproduces the inter-annual variability over most regions especially over western Canada and over regions surrounding the Great Lakes where the correlation coefficient reaches 0.6. Given CRCM5's demonstrated ability to reproduce most of the observed snow related features, we can pursue the sensitivity experiments to understand more on snow-atmosphere interactions.

Snow-temperature coupling strength in winter and spring seasons over North America are shown in Fig. 3. The coupling strength is measured by the percentage difference of inter-annual variance of temperature between the coupled and uncoupled simulations for the $850 \mathrm{hPa}$, screen level and first soil layer temperatures. The figure clearly
Inter-annual variability of SD MERRA [D.JF]

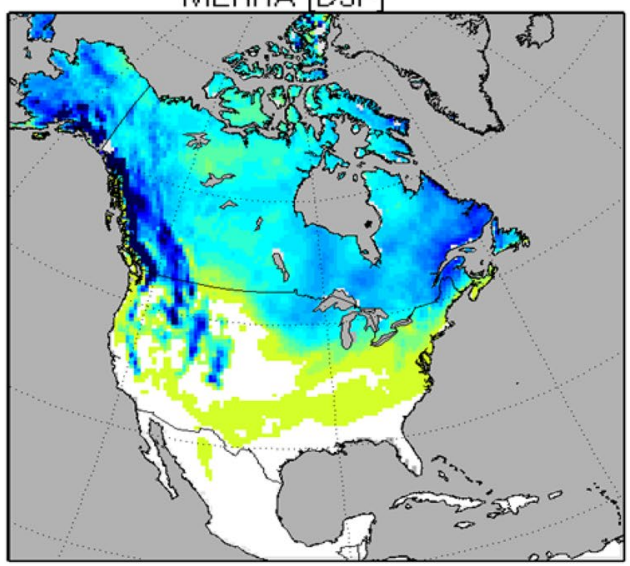

CRCM5- MERRA [D.JF]

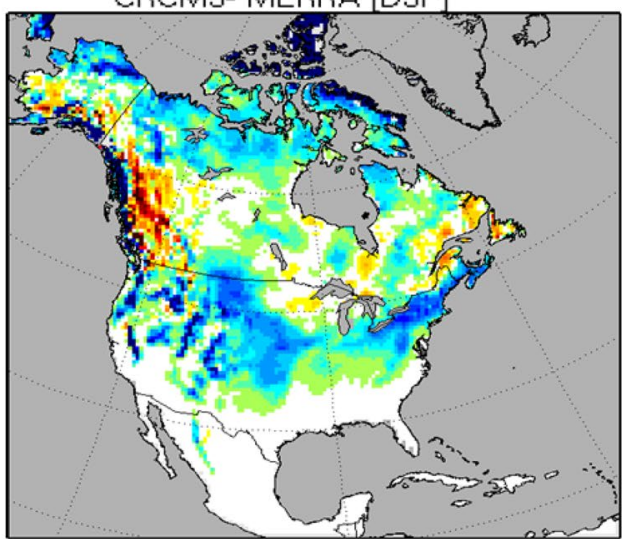

Inter-annual variability of SD MERRA [MAM]

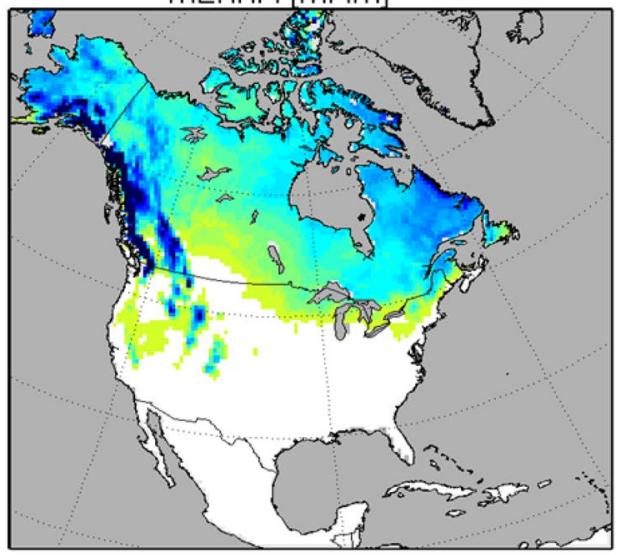

CRCM5- MERRA [MAM]

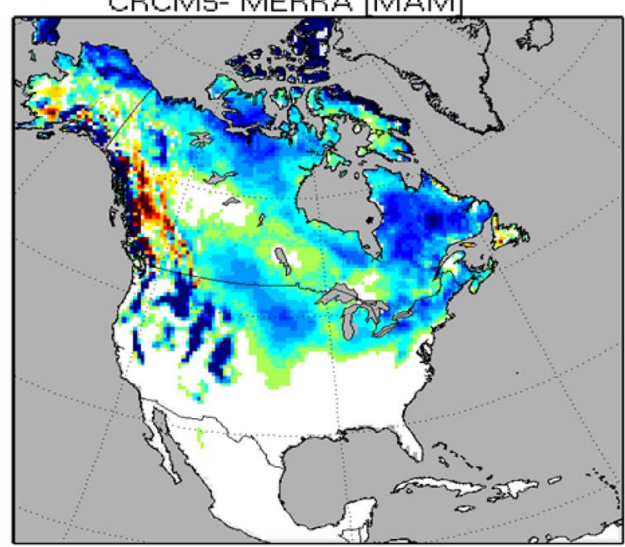

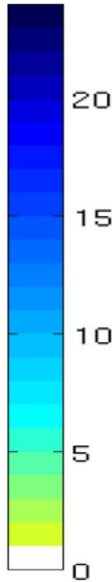

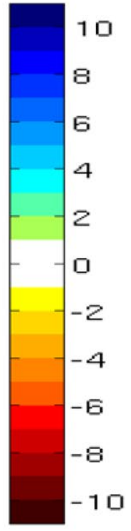

Fig. 2 Inter-annual variability of snow depth [cm] from MERRA (top row) for winter (top left) and spring (top right). Bottom row shows CRCM5 biases with respect to MERRA (i.e. CRCM5-MERRA) for winter $(l e f t)$ and spring (right) 


\section{DJF}

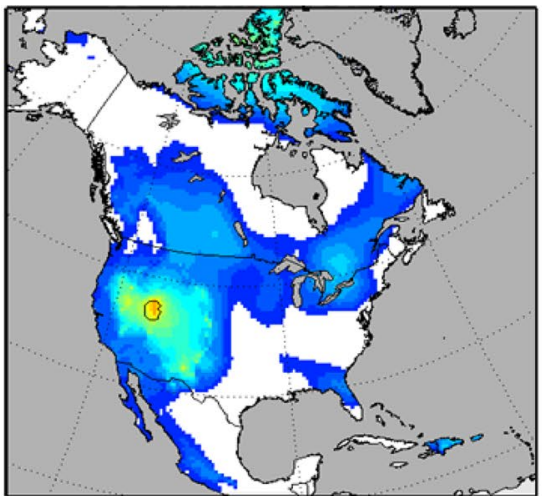

$\mathrm{T}_{850 h P a}$

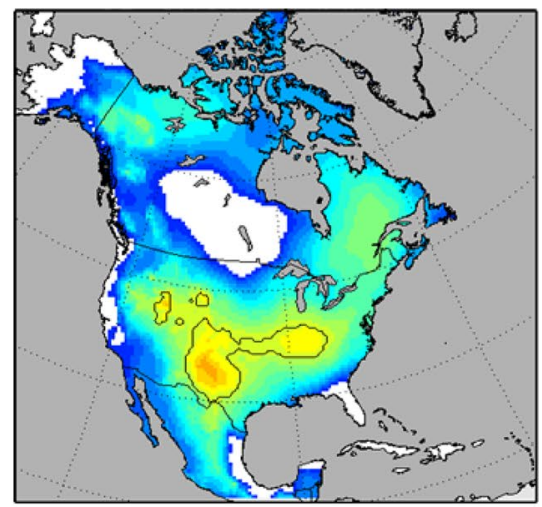

$\mathrm{T}_{2 \mathrm{~m}}$

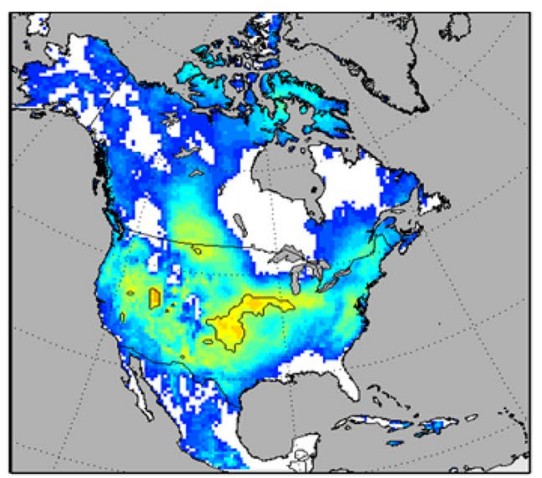

$\mathrm{T}_{\text {soil }}$

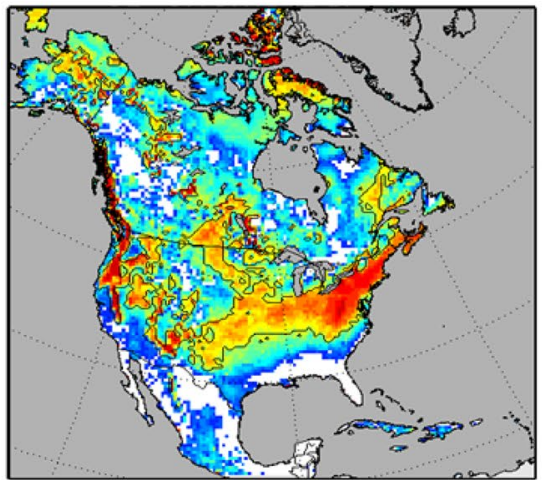

Fig. 3 Inter-annual snow-temperature coupling strength in winter (left) and spring (right) as per the percentage of variance of temperature at $850 \mathrm{hPa}$ (top), at screen level (middle) and at top soil layer

indicates that snow variation influences soil and air temperature variability over selected regions during cold seasons. The effect of snow variability on the $850 \mathrm{hPa}$ temperature

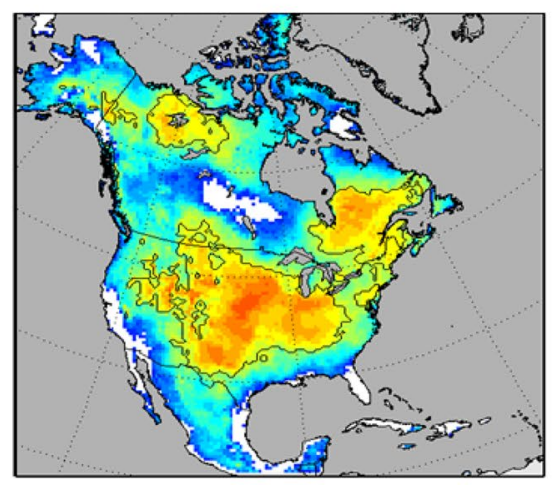

80

60

40

20

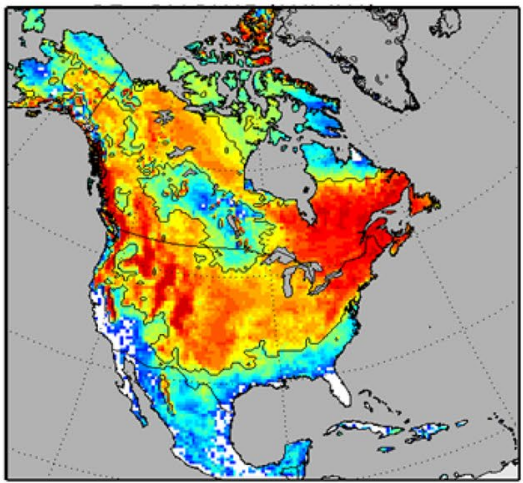

(bottom). Regions enclosed by the contour line represent statistically significant coupling at the $5 \%$ significance level

variability is much smaller than its effect on near surface air temperature and soil temperature variability and this implies that the strong effect of snow is largely confined 
to the surface and has little impact on the upper air temperature variability. It is also noted that snow is strongly coupled to soil temperature than to the near surface air temperature. This is in close agreement with Ge and Gong (2010), Alexander and Gong (2011) and Dutra et al. (2011) who also obtained similar results. The stronger effect for soil temperature is related to the snow insulation effect, which decouples the soil from extreme air temperature fluctuations (Zhang 2005). The location of maximum snow-soil temperature coupling in winter is generally over northeast US, whereas it is over the Great Plains and the Midwest for snow-air temperature coupling. The spatial pattern of the coupling strength indicates that changes in snow depth/ cover can also impact surface and atmospheric variables in the snow-free low latitude regions through non-linear processes and teleconnection.

Overall, the coupling strength is stronger in spring than in winter. The coupling strength is modest in winter and explains $40-60 \%$ of the surface temperature variability over the mountainous regions, Central U.S. and over the eastern coastal areas. The coupling is generally higher over the Great Plains, Mid-west and over the Canadian Prairies during the winter season. As the winter progresses to the melt season, the coupling not only gets stronger but also extends to high latitude regions following the freezing line. Consequently, snow variation in spring accounts for around 70\% of the near surface air temperature inter-annual variability over the Great Plains of the US and over eastern Canada. This result contradicts with Dutra et al. (2011) where they showed that the coupling strength in winter is stronger than in spring but is in agreement with $\mathrm{Xu}$ and Dirmeyer (2011) who also found stronger coupling, particularly over northern Canada, during the snow melt season compared to the snow accumulation period, although the accumulation period considered in their study is different from this study. However, caution is required when comparing the snowatmosphere coupling strength obtained in this study with that of the previous studies of Dutra et al. (2011) and Xu and Dirmeyer (2011) as the design of experiment as well as the metric used to measure the coupling strength is different in the studies, which could potentially lead to different conclusions. For instance, in Dutra et al. (2011), in their uncoupled simulation, snow albedo and snow density were prescribed in addition to snow cover and snow depth/snow mass, whereas in this study as well as in Xu and Dirmeyer (2011) these snow variables are left to evolve freely in the uncoupled simulation. Similarly, Xu and Dirmeyer (2011) performed ensembles of ten simulations (corresponding to 10 years) beginning March 1st till the end of the snow season and did not include the winter season, whereas in this study and in Dutra et al. (2011) the simulations are continuous 30-year long. Therefore the snow-atmosphere coupling metric in $\mathrm{Xu}$ and Dirmeyer (2011) is more suited to measure the impact of snow on the intra-seasonal variability, while that for the current study and Dutra et al. (2011) is directed towards measuring the impact on the interannual variability.

Figure 4 compares the impact of snow variation on surface albedo, net shortwave radiation and latent heat fluxes. For the winter season up to $90 \%$ of the surface albedo variability is explained by snow depth variability, except over the Arctic regions of Canada. As stated earlier, in CRCM5, snow cover is considered $100 \%$ for snow depth above $10 \mathrm{~cm}$. This could explain the low impact over Arctic Canada as the regions generally have more than $10 \mathrm{~cm}$ snow on the ground for most of the winter and therefore exhibits lower inter-annual variations and consequently less variation in surface albedo. In addition, the impact of snow variability on the net surface shortwave radiation, and hence the turbulent fluxes is rather small and is limited to the Midwest, the Great Plains and the Canadian Prairies but has little impact over a larger area of western Canada. The low response of net shortwave radiation indicates the dominant influence of planetary albedo (which includes the effect of clouds and water vapor) over surface albedo for most part of the domain. It is interesting to note that even though snow affects the surface albedo and the net radiation over regions north of the boreal forests and over Alaska, this is not reflected in temperature in winter months as temperature variation over these regions could be strongly influenced by either adiabatic processes or advection of anomalous cold/warm air from remote locations. In fact, Szeto (2008) demonstrated that winter temperature variation over western Canada is controlled by large-scale thermal advection rather than by diabatic processes.

During spring, additional coupling hot-spots emerge over high latitude regions with increasing insolation, except over parts of the boreal forests (Fig. 4, bottom panel). The weak coupling over the boreal forests could be due to the fact that the snow interception by the canopy is essentially the same in both coupled and uncoupled simulations. As a result, the snow variation over canopy and hence on surface albedo/radiation for grid boxes dominated by vegetation is not suppressed in the uncoupled simulation as shown in Fig. 4.

Comparing the net surface radiation (albedo effect) with the latent heat flux (hydrological effect) reveals that in the winter season, the albedo effect is higher than the hydrological effect especially over the Great Plains, the Prairies, western U.S., Alaska and over northern Canada. The high snow-temperature coupling strength in spring, however, resulted primarily from the latent heat flux (Fig. 4). This strong signal in latent heat variability is due to the snow depth variability and its subsequent melting, which gets translated into soil moisture 
Albedo
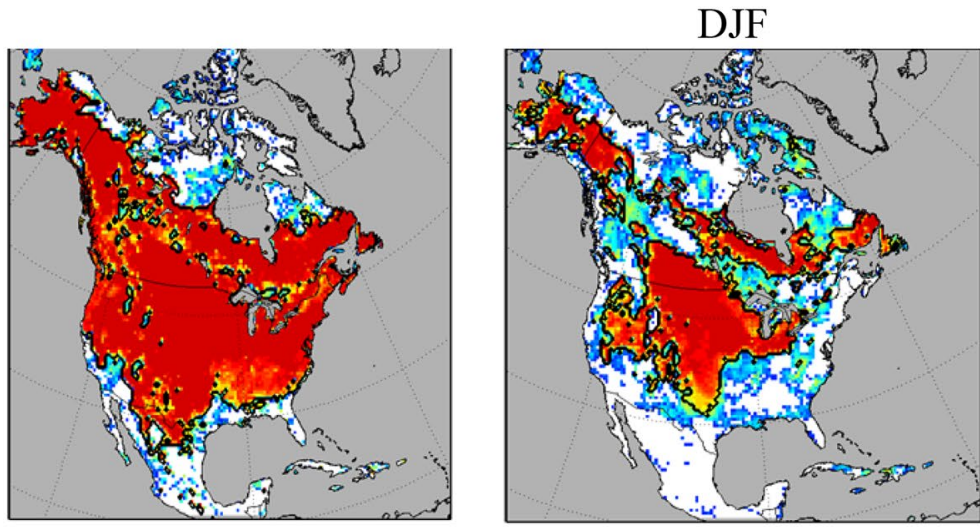

MAM
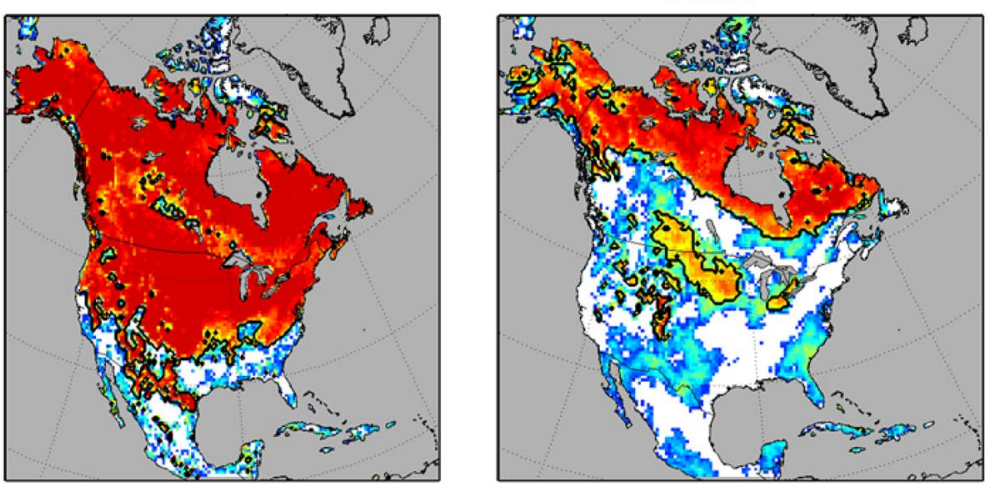

Net SW radiation

Latent heat flux
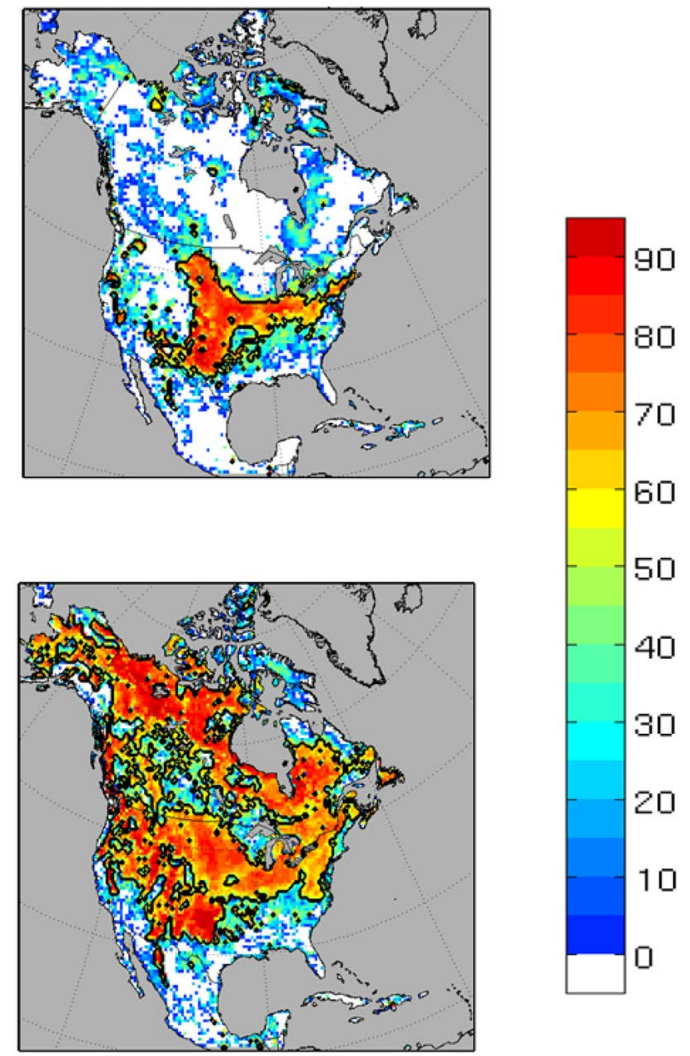

Fig. 4 Percentage of variance, due to snow-atmosphere coupling, in surface albedo (left), net shortwave radiation at the surface (middle) and latent heat flux (right) for winter (top row) and spring (bottom

variability and ultimately in the partitioning of turbulent fluxes. The influence of snow on shortwave radiation (via albedo), however, is greatly reduced in spring over most of the domain except over northern Canada. Therefore, in spring, it is the hydrological effect that control the temperature variability rather than the albedo effect.

\section{Snow-extreme temperature coupling}

Another important aspect that needs to be explored in snowatmosphere interactions is to identify the extent to which snow modulates extreme temperature events. Previous studies by Baker et al. (1992) and Vavrus (2007) suggest that snow can exert a regional influence by modulating extreme cold events such as cold-air outbreaks. Here we examined the influence of snow-atmosphere interaction on both cold and warm-spell characteristics based on reanalysis and CRCM5 simulations. Correlation values between cold-spell days and snow cover frequency in spring were computed using MERRA and ERA-Interim reanalysis dataset and row). Regions enclosed by the contour lines represent statistically significant coupling at the 5\% significance level

CRCM5 simulations (Fig. 5). Snow cover frequency is computed by counting the number of days for which the snow depth is greater than $10 \mathrm{~cm}$ for both reanalysis and CRCM5 simulations. Since snow variability is suppressed in the uncoupled CRCM5 simulation, the snow cover frequency computed from coupled CRCM5 simulation is used in the correlation analysis of both coupled and uncoupled cases.

Results from reanalysis data indicate that cold-spell days are closely correlated with snow cover frequency over most part of the domain with significantly higher values over the northern Great Plains, the Canadian Prairies and over the Mid-West. Conversely lower correlation values are observed over the Arctic regions. A significant positive correlation $(\mathrm{R}>0.6)$ is also noted in the coupled simulation between the simulated cold-spell days and snow cover frequency over the northern U.S., including the Great Plains and the Mid-West. The correlation values in the coupled CRCM5 are, however, generally over estimated, in particular over northern Canada. What is not certain from the above snow-temperature relationship in the reanalysis and the coupled simulation is whether the snow variation is 
Correlation of snow cover frequency with cold-spell days
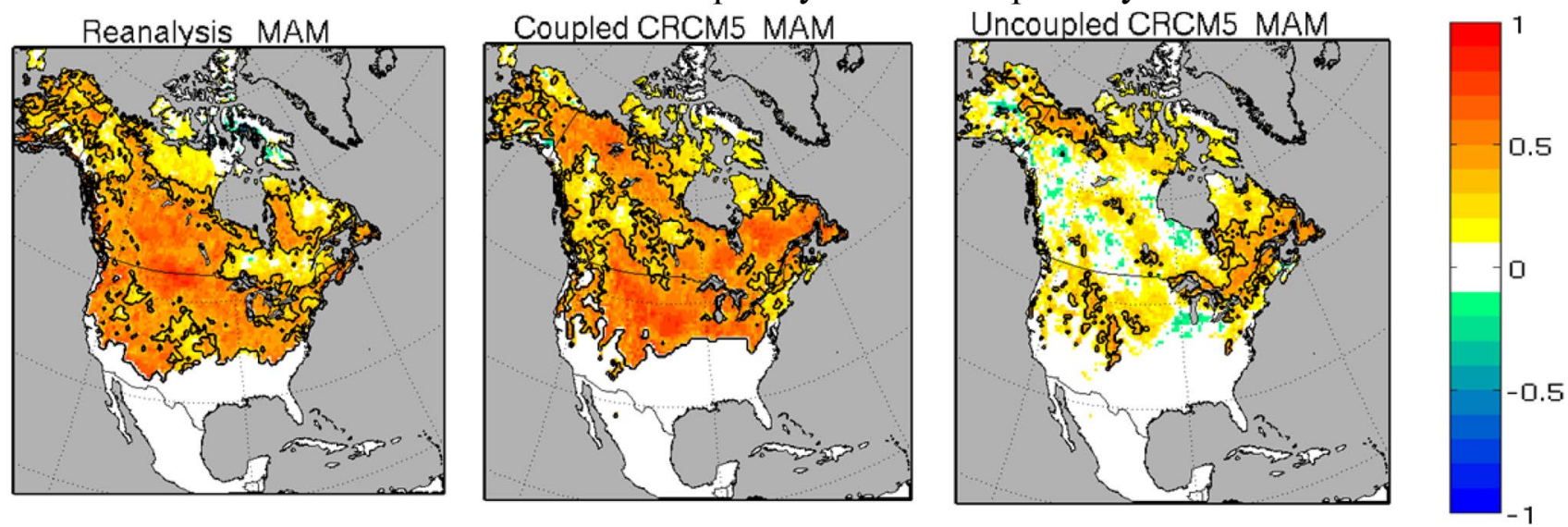

Correlation of snow cover frequency with warm-spell days
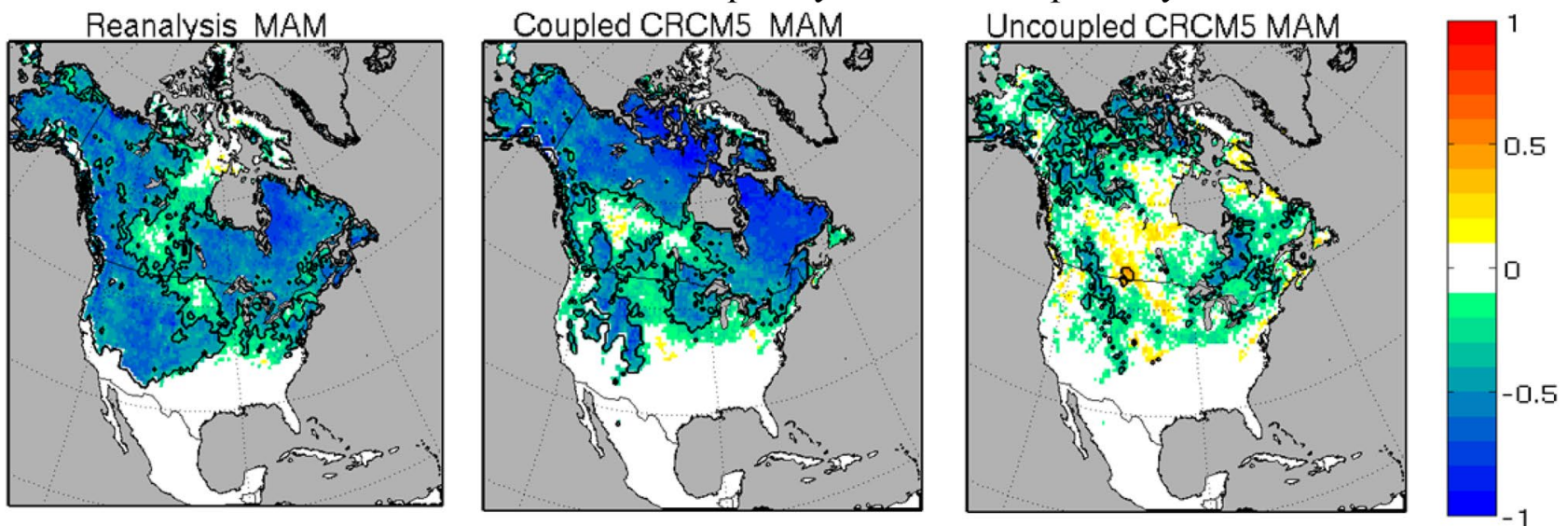

Percentage of variance, due to snow-atmosphere coupling, in cold and warm-spell days
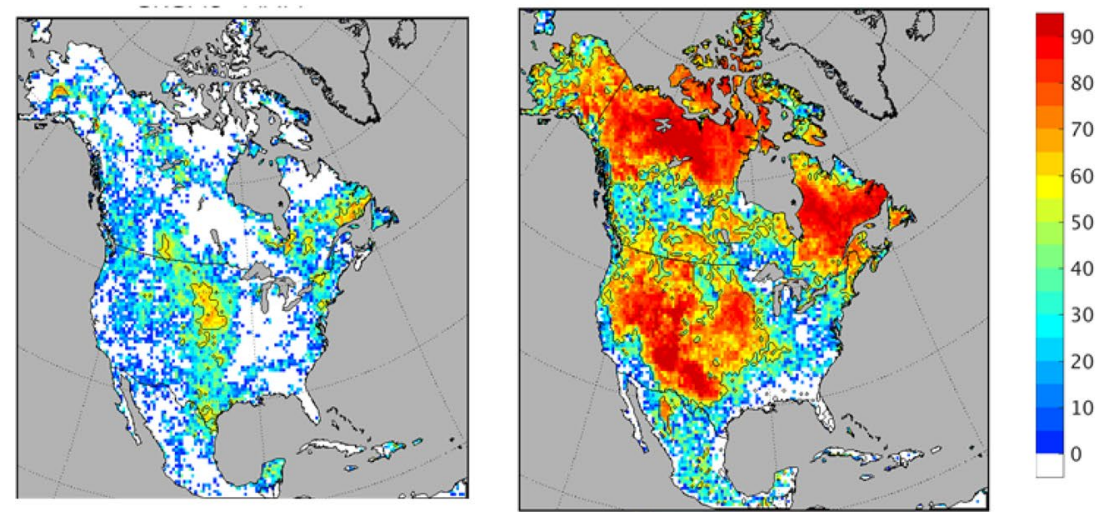

Fig. 5 Correlation of snow cover frequency with cold spell days (top panel) and warm spell days (middle panel) from MERRA and ERA-Int reanalysis (left), coupled CRCM5 simulation (middle) and uncoupled CRCM5 simulation (right). Bottom panel represents the percentage variance difference, due to snow-atmosphere coupling, in cold-spell (left) and warm-spell (right) days. Contour line denotes statistical significance at the $5 \%$ significance level 
causing the variability in temperature, or the temperature variation is causing the snow variability or another factor in the climate system (e.g., ENSO) affecting both snow and temperature variation. Since we design our experiments in such a way that the snow variation is suppressed in the uncoupled simulation, it is expected that the inter-annual variability of temperature associated with snow variation will be diminished in the uncoupled simulation. Figure 5 (top right), indeed shows that in the uncoupled CRCM5 simulations, the snow versus cold-spell relationship is significantly reduced (with correlation values around 0.2 ), suggesting that snow anomalies are important, at least, in the amplification of the cold spell days over the northern Great Plains, the Prairies and over the mid-west U.S. It has to be noted that the difference between coupled and uncoupled simulations is greater than the difference between reanalysis and control (coupled) simulations suggesting that the signal is higher than model biases and errors.

The relationship between snow cover frequency and warm spell days from reanalysis and from the two CRCM5 simulations are also shown in Fig. 5 (middle panel). Both the reanalysis and coupled CRCM5 simulation based estimates show a strong negative correlation (reaching $\mathrm{r}<-0.7$ ) between warm spell days and snow cover frequency over the high latitude regions and over the mountainous regions of western North America, but exhibits relatively lower values over the Great Plains and over the Canadian Prairies (where the cold spell days are influenced strongly by the snow cover frequency). In the CRCM5 uncoupled simulation, however, the relationship between snow cover frequency and warm-spell days is substantially reduced over the whole domain, again implying that snow variability is important in reproducing the observed snowwarm-spell relationship. The regions of strong snow-warmspell coupling are different from the regions of strong snow-cold-spell coupling. For instance, the snow coverwarm spell relationship is stronger over regions where the snow depth climatologic values are higher (Fig. 1) but is weaker where the impact of snow on cold spell is stronger i.e. over the northern Great Plains and over the Mid-west. The difference in the regions of snow-temperature extremes coupling maxima is also reflected in the variance approach (Fig. 5, bottom panel), where it clearly indicates that regions of snow-warm-spell days coupling maxima are over climatological snow rich regions whereas the snow-coldspell days coupling maxima is limited to the Great Plains of the U.S. and over the Canadian Prairies. The results also suggest that snow variation affects more the variability of warm-spell days than the variability of cold-spell days. The sustained warm-spell events over high snow accumulation regions, appear to be related to the reduction of snow through melting and the associated increases in the absorbed shortwave radiation.

\subsection{The 2002 extreme cold spring}

For identifying the role that snow may have in amplifying/attenuating extreme cold air outbreak events, investigation is carried out using observations as well as from CRCM5 coupled and uncoupled simulations for the year 2002. The year 2002 is chosen as it is the coldest spring for the 1981-2010 period for the region enclosed by $45 \mathrm{~N}-60 \mathrm{~N}$ latitude and $100 \mathrm{~W}-123 \mathrm{~W}$ longitude over northwest North America (Fig. 6) both in observation and in reanalysis dataset.

Figure 7 displays the spatial pattern of the number of cold spell days for the spring of 2002 from observation, reanalysis and coupled and uncoupled CRCM5 simulations. Both observation and reanalysis agree on the locations of the highest number of cold spell days, i.e., over northwest North America, with the number of cold spell days (cold air outbreak) reaching more than 16. The coupled CRCM5 simulation captures well the spatial pattern over northwest Canada, despite the underestimation in the number of cold spell days. The coupled simulation also shows a secondary peak over north-eastern U.S., which is not visible in the observation or reanalysis. This overestimation of cold spell over north-eastern U.S. is linked to the overestimation of snow cover frequency (Fig. 8, bottom rows) in the coupled simulation. In the uncoupled CRCM5 simulation, the number of cold-spell days is substantially reduced over most part of the domain including northwest America. This indicates that having an interactive snow is an important condition in order to reproduce such an extreme climate event with reasonable accuracy. This result implies that, even if extreme cold events such as cold air outbreaks are triggered and initiated by large-scale atmospheric phenomenon (Vavrus et al. 2006), snow-atmosphere interactions contribute to the persistence of these events. In fact, Fig. 8 (top and middle row) shows the anomaly map of the $500 \mathrm{hPa}$ height and wind anomaly at $700 \mathrm{hPa}$ (with respect to long-term

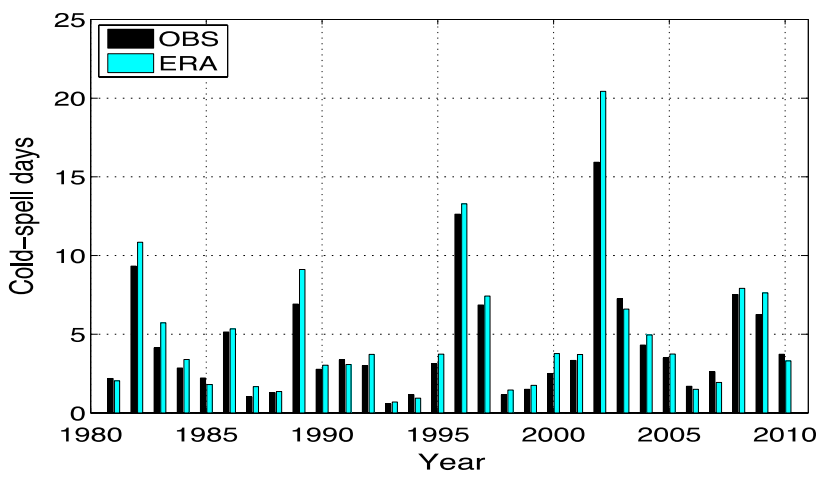

Fig. 6 Number of cold-spell days over northwest North America $\left(45^{\circ} \mathrm{N}-60^{\circ} \mathrm{N}, 100^{\circ} \mathrm{W}-123^{\circ} \mathrm{W}\right)$, based on ERA (cyan) and gridded station observations (black) 

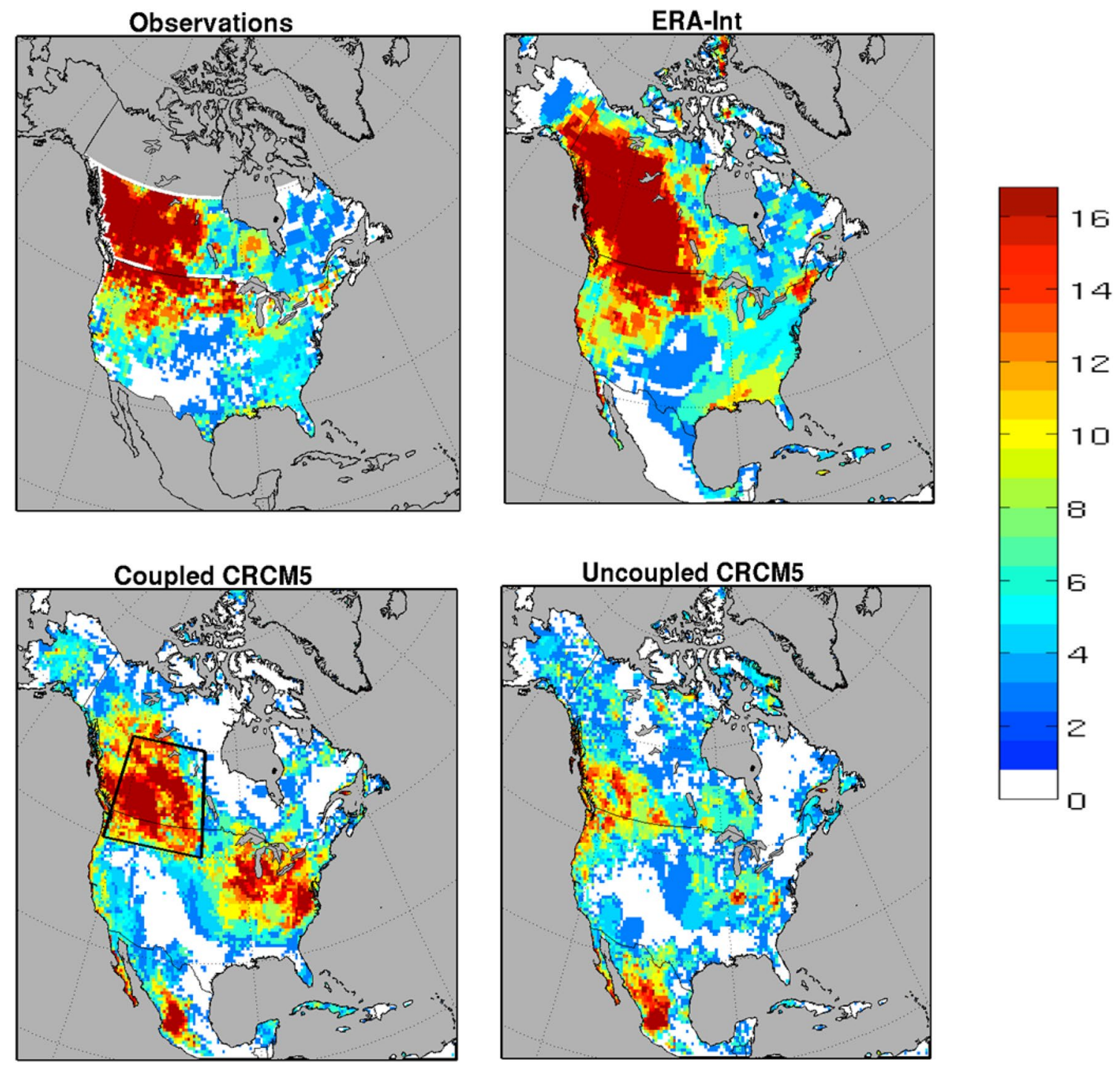

Fig. 7 Cold-spell days (CSD) for the year 2002 from gridded station observation (top left), ERA-Interim reanalysis (top right), from CRCM5 coupled (bottom left) and uncoupled (bottom right) simulations

average) associated with the 2002 spring as an example of such large-scale atmosphere features. The anomaly map based on reanalysis indicates that the cold-spells are associated with high pressure anomaly over NE Pacific and low pressure anomaly over central Canada that favours northeasterly flow anomaly in between these high and low anomalies. A similar pattern of height and wind anomalies is also noticeable in CRCM5 simulations over the same region, although the lows are slightly weaker suggesting that the large scale circulation anomalies associated with the cold spells over northwest are reproduced fairly well.

\subsection{ENSO composites}

Analysis is also carried out to investigate the response of warm spells during El-Nino events and to assess the role of the interaction of large-scale mode of variability, such as ENSO, with surface condition on extreme events. Attention is given to warm spells, since cold spells are less sensitive to ENSO forcings (Gershunov and Barnett 1998). The SST anomalies in the Nino 3 region from Climate Prediction Centre (CPC) (http://www.cpc.ncep. noaa.gov/products/analysis_monitoring/ensostuff/ensoyears.shtml) has been used to construct warm/cold composites of ENSO for the 1981-2010 period. The composites are based on the four strongest El-Nino events during spring season. The strongest El-Nino events correspond to events with ENSO index above 0.9. The years selected for analysis are 1983, 1987, 1992 and 1998.

Figure 9 shows the observed, reanalysed and simulated composites of maximum duration of warm spells during El-Nino years. The longest duration of warm spells, 
Reanalysis
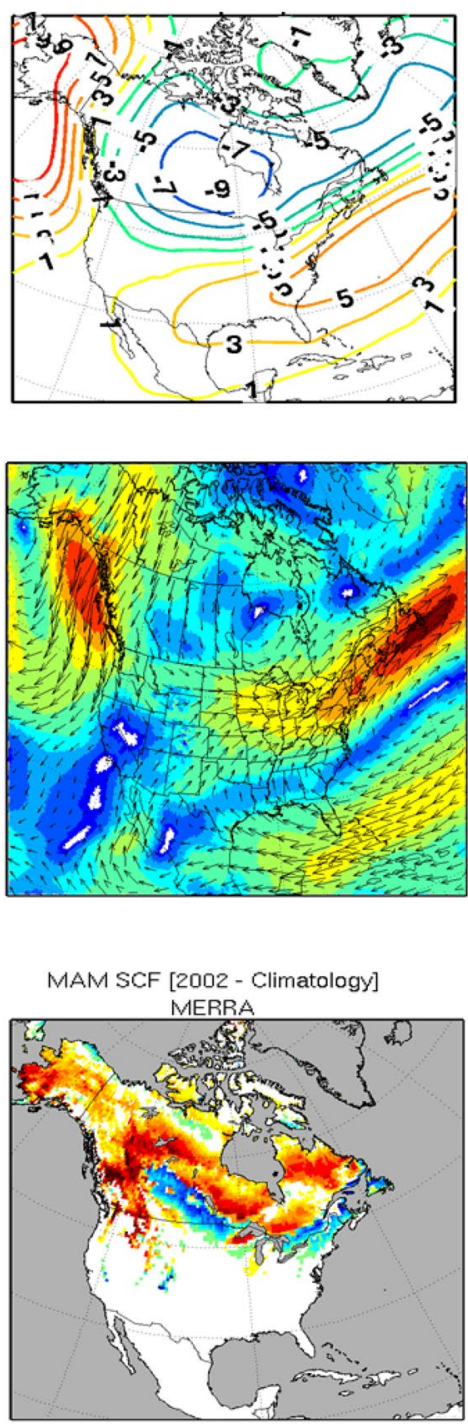

Coupled
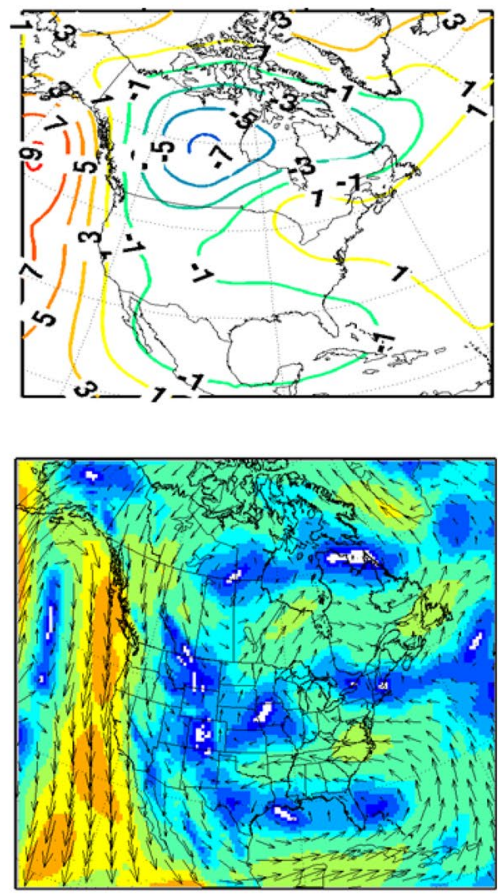

MAM SCF [2002 - Climatology]

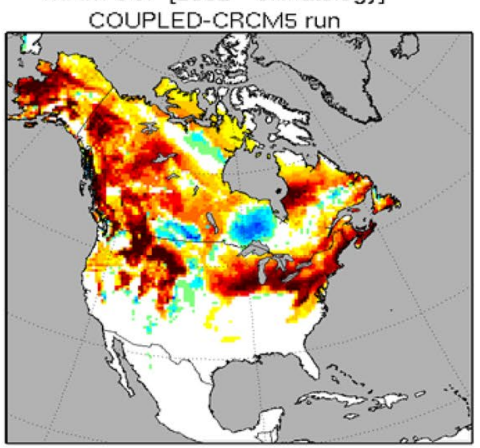

Uncoupled
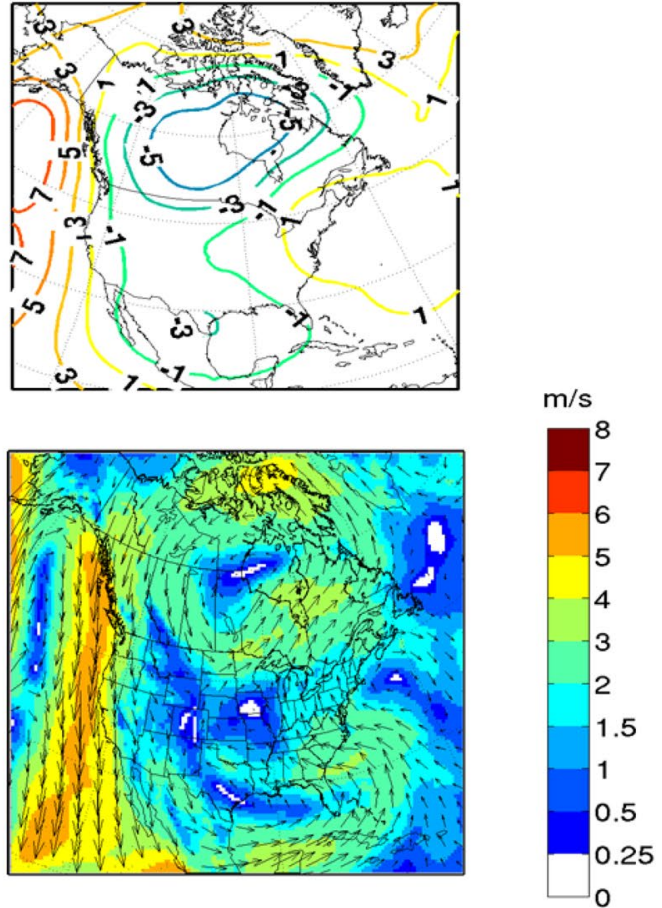

MAM SCF [2002 - Climatology]

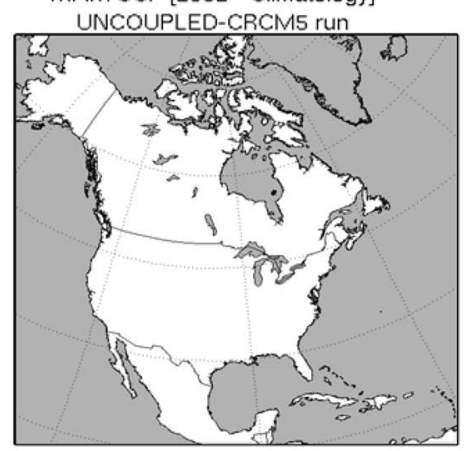

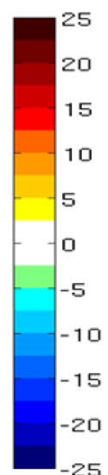

Fig. 8 Composites of $500 \mathrm{hPa}$ height anomaly (2002—climatology, top row) [in dam], wind anomaly at $700 \mathrm{hPa}$ (middle row) [in m/s] and snow cover frequency $(S C F)$ anomaly (bottom row), for reanalysis (left), coupled (middle) and uncoupled CRCM5 (right) simulations

reaching up to 7 consecutive days, are found over the northwest and the eastern parts of North America, in both observation and reanalysis. Previous observational studies also found that, positive ENSO events are associated with significantly warmer spring temperature anomalies over western Canada (Shabbar and Khandekar 1996) and over northwest Pacific of the U.S. (Wolter et al. 1999). The coupled CRCM5 simulation is able to reproduce these observed patterns of the longest warm-spell duration, although the highest values in the model are shifted southward and the peak values over western and eastern
Canada are underestimated. In comparison, in the uncoupled CRCM5 simulation, the maximum warm spell duration over western North America is substantially reduced by more than $50 \%$. Whereas over the eastern part of the domain the reduction in the longest duration of warm spells are smaller suggesting that snow-atmosphere interaction play an active role in amplifying the duration of warm spells over the western U.S. and over Canada. The eastern part of the U.S., on the other hand, is influenced less by surface condition but more by large scale atmospheric forcing. 

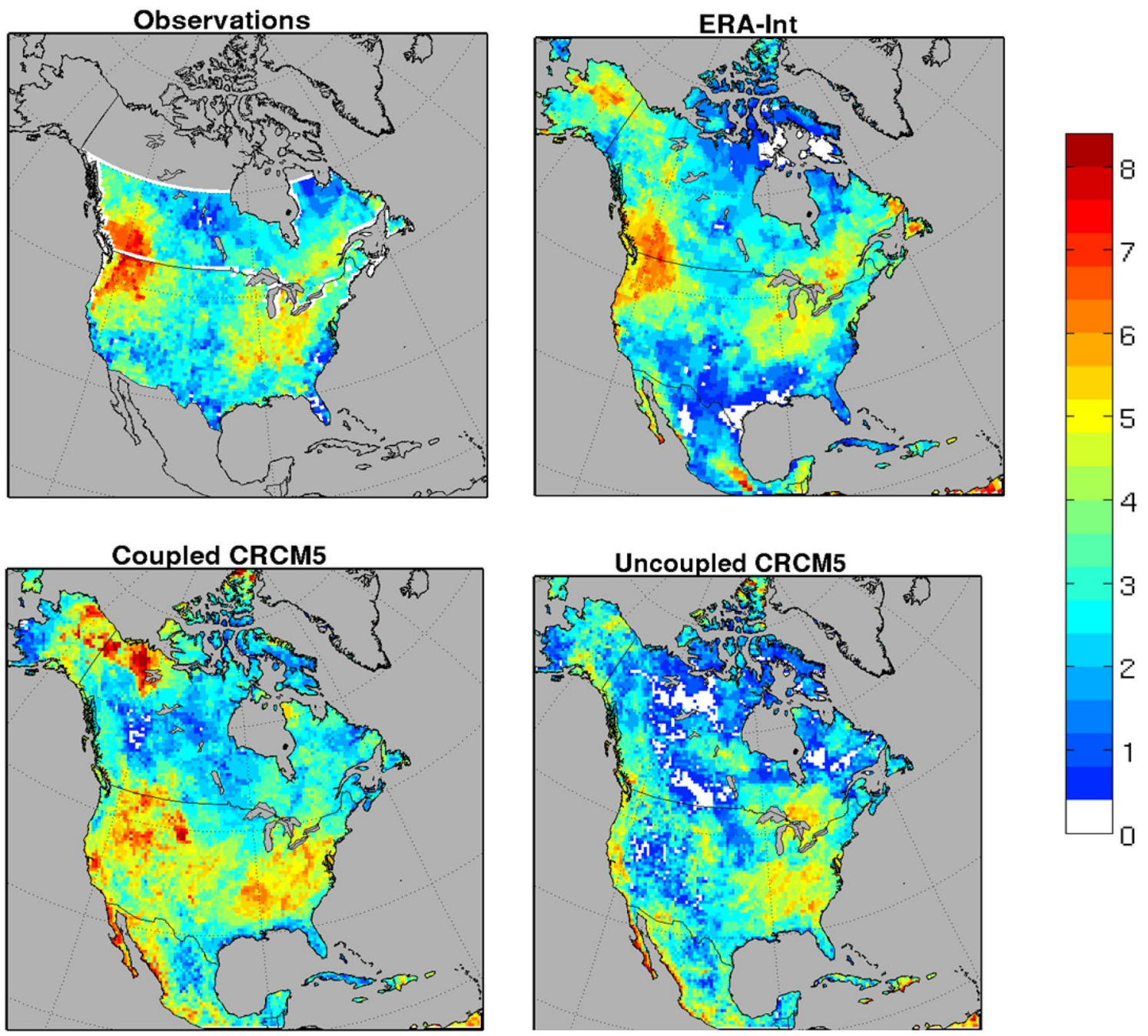

Fig. 9 Composites of maximum warm-spell durations during the spring season for El-Nino years from gridded station observation (top left), ERA-Interim reanalysis (top right), CRCM5 coupled (bottom left) and uncoupled (bottom right) simulations

\section{Summary and conclusions}

This study presents the snow-atmosphere coupling characteristics over North America and its impact on selected extreme temperature characteristics. Two 30-year long simulations were carried out using CRCM5 driven by ERAInterim reanalysis with prescribed (uncoupled) and evolving (coupled) snow depth/cover. In the coupled simulation, snow and atmosphere are allowed to interact at every model time step but in the uncoupled simulation, the snow depth/ cover evolution is replaced with climatology, derived from the coupled simulation. The aims of the experiments are to examine regions of important snow-atmosphere coupling, to quantify the coupling strength as well as to investigate the role of snow in modulating extreme events.

According to the analysis, strong snow-atmosphere coupling is noted over the Mid-west, the Great Plains and the
Canadian Prairies in winter and these regions of strong coupling extend further north in spring towards eastern Canada and the region north of the boreal forest following the solar cycle. In the coupled simulations, snow variations account for $40-60 \%$ of the winter temperature variability over the strong snow-temperature coupling regions. The contribution of snow becomes higher in spring because its contribution reaches more than $70 \%$ and furthermore the regions of snow-atmosphere coupling extend north of the boreal forests. The impact of snow variability is more reflected in the soil temperature variability than the air temperature variability. This finding is in agreement with Ge and Gong (2010) and illustrates that snow affects soil temperature not only via snow cover extent but also via snow depth by insulating the soil from extreme air temperature.

Analysis suggests links between warm/cold-spell characteristics and snow-atmosphere coupling regions. The 
regions, however, where the snow variability influences warm and cold spells are different. For instance, warm spell characteristics over northeast Canada and Rockies appear to be more sensitive to snow variability as reflected in the high correlation values between the two. However, the snow cover-cold spell correlations are high mainly over the Great Plains, Mid-west and over the Canadian Prairies. Furthermore, this study reveals the amplifying effect of snow-atmosphere coupling on temperature extremes from the case study of the spring 2002 extreme cold spells over northwest America as well as from analysis of warm extremes during strong El-Nino years using observations and regional climate model experiments. The regional climate model experiments clearly show a strong contribution of snow-atmosphere interaction to the duration of cold spells during the spring of 2002 and to the maximum warm spells durations during strong ENSO events.

Given climate models project a decline in snow cover over high latitude regions for the twenty-first century, future work is needed to understand how the present-day snow-atmosphere coupling regions would change in future climate as well as how future snow-atmosphere coupling would contribute to the projected changes in extremes.

One caveat of this study is that the results are based on a single regional climate model. Given that the results are heavily dependent on the snow-related parameterizations, future work using multiple regional climate models will be beneficial to better quantify the uncertainties in snow-atmosphere coupling and the role that snow plays in modulating climate extremes.

Acknowledgements This research was carried out within the framework of the Canadian Network for Regional Climate and Weather Processes (CNRCWP) funded by the Natural Sciences and Engineering Research Council (NSERC) [Grant No: 433915-2012] of Canada. We thank NASA and the European Centre for Medium-Range Weather Forecasts (ECMWF) for MERRA and ERA-Interim reanalysis products respectively. The CRCM5 simulations considered in this study were performed on the supercomputer managed by Calcul Québec and Compute Canada.

Open Access This article is distributed under the terms of the Creative Commons Attribution 4.0 International License (http:// creativecommons.org/licenses/by/4.0/), which permits unrestricted use, distribution, and reproduction in any medium, provided you give appropriate credit to the original author(s) and the source, provide a link to the Creative Commons license, and indicate if changes were made.

\section{References}

Alexander P, Gong G (2011) Modeled surface air temperature response to snow depth variability. J Geophys Res 116(D14). doi:10.1029/2010JD014908
Baker DG, Ruschy DL, Skaggs RH, Wall DB (1992) Air temperature and radiation depressions associated with a snow cover. $\mathrm{J}$ Appl Meteorol 31(3):247-254

Bélair S, Mailhot J, Girard C, Vaillancourt P (2005) Boundary layer and shallow cumulus clouds in a medium-range forecast of a large-scale weather system. Mon Weather Rev 133(7):1938-1960

Benoit R, Côté J, Mailhot J (1989) Inclusion of a TKE boundary layer parameterization in the Canadian regional finite-element model. Mon Weather Rev 117(8):1726-1750

Betts AK, Desjardins R, Worth D, Wang SS, Li JH (2014) Coupling of winter climate transitions to snow and clouds over the Prairies. J Geophys Res 119(3):1118-1139

Brun E, David P, Sudul M, Brunot G (1992) A numerical model to simulate snow-cover stratigraphy for operational avalanche forecasting. J Glaciol 38(128):13-22

Cohen J, Entekhabi D (2001) The influence of snow cover on Northern Hemisphere climate variability. Atmos Ocean 39(1):35-53

Cohen J, Rind D (1991) The effect of snow cover on the climate. J Clim 4(7):689-706

Côté J, Gravel S, Méthot A, Patoine A, Roch M, Staniforth A (1998) The operational CMC-MRB global environmental multiscale (GEM) model. Part I: design considerations and formulation. Mon Weather Rev 126(6):1373-1395

Cox P, Betts R, Bunton C, Essery R, Rowntree P, Smith J (1999) The impact of new land surface physics on the GCM simulation of climate and climate sensitivity. Clim Dyn 15(3):183-203

Dee D, Uppala S, Simmons A, Berrisford P, Poli P, Kobayashi S, Andrae U, Balmaseda M, Balsamo G, Bauer P et al (2011) The ERA-Interim reanalysis: configuration and performance of the data assimilation system. Q J R Meteorol Soc 137(656):553-597

Delage Y (1997) Parameterising sub-grid scale vertical transport in atmospheric models under statically stable conditions. Bound Layer Meteorol 82(1):23-48

Diro GT, Sushama L, Martynov A, Jeong DI, Verseghy D, Winger K (2014) Land-atmosphere coupling over North America in CRCM5. J Geophys Res: Atmos 119(21):11955-11972. doi:10. 1002/2014JD021677

Douville H, Royer J-F, Mahfouf J-F (1995) A new snow parameterization for the Meteo-France climate model. Clim Dyn 12(1):21-35

Dutra E, Balsamo G, Viterbo P, Miranda PM, Beljaars A, Schär C, Elder K (2010) An improved snow scheme for the ECMWF land surface model: description and offline validation. J Hydrometeorol 11(4):899-916

Dutra E, Schär C, Viterbo P, Miranda P (2011) Land-atmosphere coupling associated with snow cover. Geophys Res Lett 38(15). doi: 10.1029/2011GL048435

Essery R, Morin S, Lejeune Y, Ménard CB (2013) A comparison of 1701 snow models using observations from an alpine site. Adv Water Resour 55:131-148

Ge Y, Gong G (2010) Land surface insulation response to snow depth variability. J Geophys Res 115(D8). doi:10.1029/2009JD012798

Gershunov A, Barnett TP (1998) ENSO influence on intraseasonal extreme rainfall and temperature frequencies in the contiguous United States: observations and model results (vol 11, pg 1575, 1998). J Clim 11(11):3062-3065

Gong G, Entekhabi D, Cohen J, Robinson D (2004). Sensitivity of atmospheric response to modeled snow anomaly characteristics. J Geophys Res 109(D6). doi:10.1029/2003JD004160

Groisman PY, Karl TR, Knight RW, Stenchikov GL (1994) Changes of snow cover, temperature, and radiative heat balance over the northern hemisphere. J Clim 7(11):1633-1656

Guo Z, Dirmeyer PA, Koster RD, Sud Y, Bonan G, Oleson KW, Chan E, Verseghy D, Cox P, Gordon C et al (2006) GLACE: the global land-atmosphere coupling experiment. Part II: analysis. J Hydrometeorol 7(4):611-625 
Hopkinson RF, McKenney DW, Milewska EJ, Hutchinson MF, Papadopol P, Vincent LA (2011) Impact of aligning climatological day on gridding daily maximum-minimum temperature and precipitation over Canada. J Appl Meteorol Climatol 50(8):1654-1665

Hutchinson MF, McKenney DW, Lawrence K, Pedlar JH, Hopkinson RF, Milewska E, Papadopol P (2009) Development and testing of Canada-wide interpolated spatial models of daily minimummaximum temperature and precipitation for 1961-2003. J Appl Meteorol Climatol 48(4):725-741.

Jeong DI, Sushama L, Diro GT, Khaliq MN, Beltrami H, Caya D (2016) Projected changes to high temperature events for Canada based on a regional climate model ensemble. Clim Dyn 46(9-10):3163-3180

Kain J, Fritsch J (1992) The role of the convective "trigger function" in numerical forecasts of mesoscale convective systems. Meteorol Atmos Phys 49(1-4):93-106

Karl TR, Groisman PY, Knight RW, Heim RR Jr (1993) Recent variations of snow cover and snowfall in North America and their relation to precipitation and temperature variations. J Clim 6(7):1327-1344

Koster RD, Sud Y, Guo Z, Dirmeyer PA, Bonan G, Oleson KW, Chan E, Verseghy D, Cox P, Davies H et al (2006) GLACE: the global land-atmosphere coupling experiment. Part I: overview. J Hydrometeorol 7(4):590-610

Kumar A, Yang F (2003) Comparative influence of snow and SST variability on extratropical climate in northern winter. J Clim 16(13):2248-2261

Li J, Barker H (2005) A radiation algorithm with correlated-k distribution. Part I: local thermal equilibrium. J Atmos Sci 62(2):286-309

Martynov A, Sushama L, Laprise R, Winger K, Dugas B (2012) Interactive lakes in the Canadian Regional Climate Model, version 5: the role of lakes in the regional climate of North America. Tellus A $64: 16226$

Martynov A, Laprise R, Sushama L, Winger K, Šeparović L, Dugas B (2013) Reanalysis-driven climate simulation over CORDEX North America domain using the Canadian Regional Climate Model, version 5: model performance evaluation. Clim Dyn 41(11-12):2973-3005

Maurer E, Wood A, Adam J, Lettenmaier D, Nijssen B (2002) A long-term hydrologically based dataset of land surface fluxes and states for the conterminous United States*. J Clim 15(22):3237-3251

Niu GY, Yang ZL (2007) An observation-based formulation of snow cover fraction and its evaluation over large North American river basins. J Geophys Res 112(D21). doi:10.1029/2007JD008674

Pedersen CA, Winther J-G (2005) Intercomparison and validation of snow albedo parameterization schemes in climate models. Clim Dyn 25(4):351-362

Pirazzini R (2009) Challenges in snow and ice Albedo parameterizations. Geophysica 45(1-2):41-62

Rienecker MM, Suarez MJ, Gelaro R, Todling R, Bacmeister J, Liu E, Bosilovich MG, Schubert SD, Takacs L, Kim G-K (2011) MERRA: NASA's modern-era retrospective analysis for research and applications. J Clim 24(14):3624-3648

Roeckner E, Bäuml G, Bonaventura L, Brokopf R, Esch M, Giorgetta M, et al (2003) The atmospheric general circulation model ECHAM 5. PART I: model description. Report/MPI für Meteorologie, 349
Shabbar A, Khandekar M (1996) The impact of el Nino-Southern oscillation on the temperature field over Canada: research note. Atmos Ocean 34(2):401-416

Snauffer AM, Hsieh WW, Cannon AJ (2016) Comparison of gridded snow water equivalent products with in situ measurements in British Columbia, Canada. J Hydrol 541:714-726

Sobolowski S, Gong G, Ting M (2010) Modeled climate state and dynamic responses to anomalous North American snow cover. J Clim 23(3):785-799

Sundqvist H, Berge E, Kristjánsson JE (1989) Condensation and cloud parameterization studies with a mesoscale numerical weather prediction model. Mon Weather Rev 117(8):1641-1657

Szeto KK (2008) On the extreme variability and change of cold-season temperatures in northwest Canada. J Clim 21(1):94-113

Vavrus S (2007) The role of terrestrial snow cover in the climate system. Clim Dyn 29(1):73-88

Vavrus S, Walsh J, Chapman W, Portis D (2006) The behavior of extreme cold air outbreaks under greenhouse warming. Int J Climatol 26(9):1133-1147

Verseghy DL (1991) CLASS—A Canadian land surface scheme for GCMs. I. Soil model. Int J Climatol 11(2):111-133

Verseghy D (2009) CLASS the canadian land surface scheme (version 3.4), Technical report, Climate Research Division, Science and Tecnology Branch, Enviornment Canda, 2009. 107

Verseghy D, McFarlane N, Lazare M (1993) CLASS—A Canadian land surface scheme for GCMs, II. Vegetation model and coupled runs. Int J Climatol 13(4):347-370

Verseghy D, Brown R, Wang L (2017) Evaluation of CLASS snow simulation over eastern Canada. J Hydrometeorol 18(5):1205-1225

Walsh JE, Tucek DR, Peterson MR (1982) Seasonal snow cover and short-term climatic fluctuations over the United States. Mon Weather Rev 110(10):1474-1486

Walsh JE, Jasperson WH, Ross B (1985) Influences of snow cover and soil moisture on monthly air temperature. Mon Weather Rev 113(5):756-768

Wolter K, Dole RM, Smith CA (1999) Short-term climate extremes over the continental United States and ENSO. Part I: seasonal temperatures. J Clim 12(11):3255-3272

Xu L, Dirmeyer P (2011) Snow-atmosphere coupling strength in a global atmospheric model. Geophys Res Lett 38(13). doi:10.10 29/2011GL048049

Xu L, Dirmeyer P (2013) Snow-atmosphere coupling strength. Part I: effect of model biases. J Hydrometeorol 14(2):389-403

Xue Y, Sellers P, Kinter JL, Shukla J (1991) A simplified biosphere model for global climate studies. J Clim 4(3):345-364

Yang F, Kumar A, Wang W, H.-M. H. Juang, Kanamitsu M (2001) Snow-albedo feedback and seasonal climate variability over North America. J Clim 14(22):4245-4248

Zadra A, Caya D, Côté J, Dugas B, Jones C, Laprise R, Winger K, Caron L-P (2008) The next Canadian regional climate model. Phys Can 64(2):75-83

Zadra A, McTaggart-Cowan R, Roch M (2012) Recent changes to the orographic blocking. Seminar presentation, RPN, Dorval, Canada, 30 March 2012

Zhang T (2005) Influence of the seasonal snow cover on the ground thermal regime: an overview. Rev Geophys 43. doi:10.1029/20 04RG000157 